\title{
Biology and Management of Dollar Spot (Sclerotinia homoeocarpa); an Important Disease of Turfgrass
}

\author{
Brenda Walsh, Stephanie S. Ikeda, and Greg J. Boland \\ Department of Environmental Biology, University of Guelph, Guelph, ON, N1G 2W1, Canada
}

\section{INTRODUCTION}

Turfgrasses have been utilized by humans for $>10$ centuries to enhance their environment, but the modern turfgrass industry developed primarily during the past three decades, largely in response to increased population growth and urbanization. Turfgrass culture represents an important economic component of horticulture in North America with annual expenditures of $\$ 25$ to $\$ 45$ billion in the United States between 1982 and 1993 (Beard and Green, 1994; Gibeault and Cockerham, 1985). In return, turfgrass provides numerous benefits, including functional (e.g., reduction of soil erosion, pollution, and noise), recreational (e.g., provision of recreational surfaces for

Received for publication 13 Nov. 1997. Accepted for publication 3 May 1998 . We gratefully acknowledge the taxonomic assistance of Carole Ann Lacroix of the Univ. of Guelph Herbarium, and the financial assistance of the Natural Sciences Engineering and Research Council and the Ontario Ministry of Agriculture, Food and Rural Affairs. The cost of publishing this paper was defrayed in part by the payment of page charges. Under postal regulations, this paper therefore must be hereby marked advertisement solely to indicate this fact. improved health and safety), and aesthetic benefits (e.g., improved aesthetic value and community pride) (Beard and Green, 1994; Gordon et al., 1996). Because of these economic and environmental benefits, turfgrass and turfgrass health have become increasingly important.

Dollar spot (Sclerotinia homoeocarpa F.T. Bennett) is one of the most important diseases that affect turfgrass; it can cause considerable damage, particularly to highly maintained golf course putting greens, closely mown fairways, and bowling greens (Goodman and Burpee, 1991). This disease can also damage less intensively managed turfgrass grown on home lawns, recreational and athletic facilities, and educational or industrial properties. Dollar spot reduces the aesthetic and playing quality of infected turf, and can contribute to weed encroachment and plant death (Fig. 1) (Smith et al., 1989). Dollar spot is a widespread disease that affects many turfgrass species throughout North America, Central America, Australia, New Zealand, Japan, the British Isles, and continental Europe (Couch, 1995; Fenstermacher, 1980; Vargas, 1994). Except for western Canada and the Pacific northwest region of the United States, dollar spot is the most common disease of turf in North America (Couch, 1995). The persistent nature of this disease in turfgrass swards often requires intensive control measures. As a result, more money is spent to manage dollar spot than to control any other turfgrass disease on golf courses (Goodman and Burpee, 1991).

\section{DISEASE SYMPTOMS}

On individual blades of grass, the first symptom of disease is yellow-green blotches that progress to a water-soaked appearance (Smith, 1955). As the disease advances, infected tissues bleach to a straw-colored tan with reddish-brown borders, and lesions often enlarge across the entire leaf (Fig. 2) (Smiley et al., 1992; Smith, 1955). Reddish-brown lesion borders do not typically occur on annual bluegrass (Poa annua L.) (Couch, 1995; Vargas, 1994). Usually, entire leaves are blighted but, in some cases, only portions of a leaf become necrotic (Couch, 1995; Smiley et al., 1992).

Symptoms of dollar spot on turfgrass swards vary according to turfgrass species and management practices. On closely mown turf, such as that on golf course putting greens, sunken, circular, straw-colored patches develop that

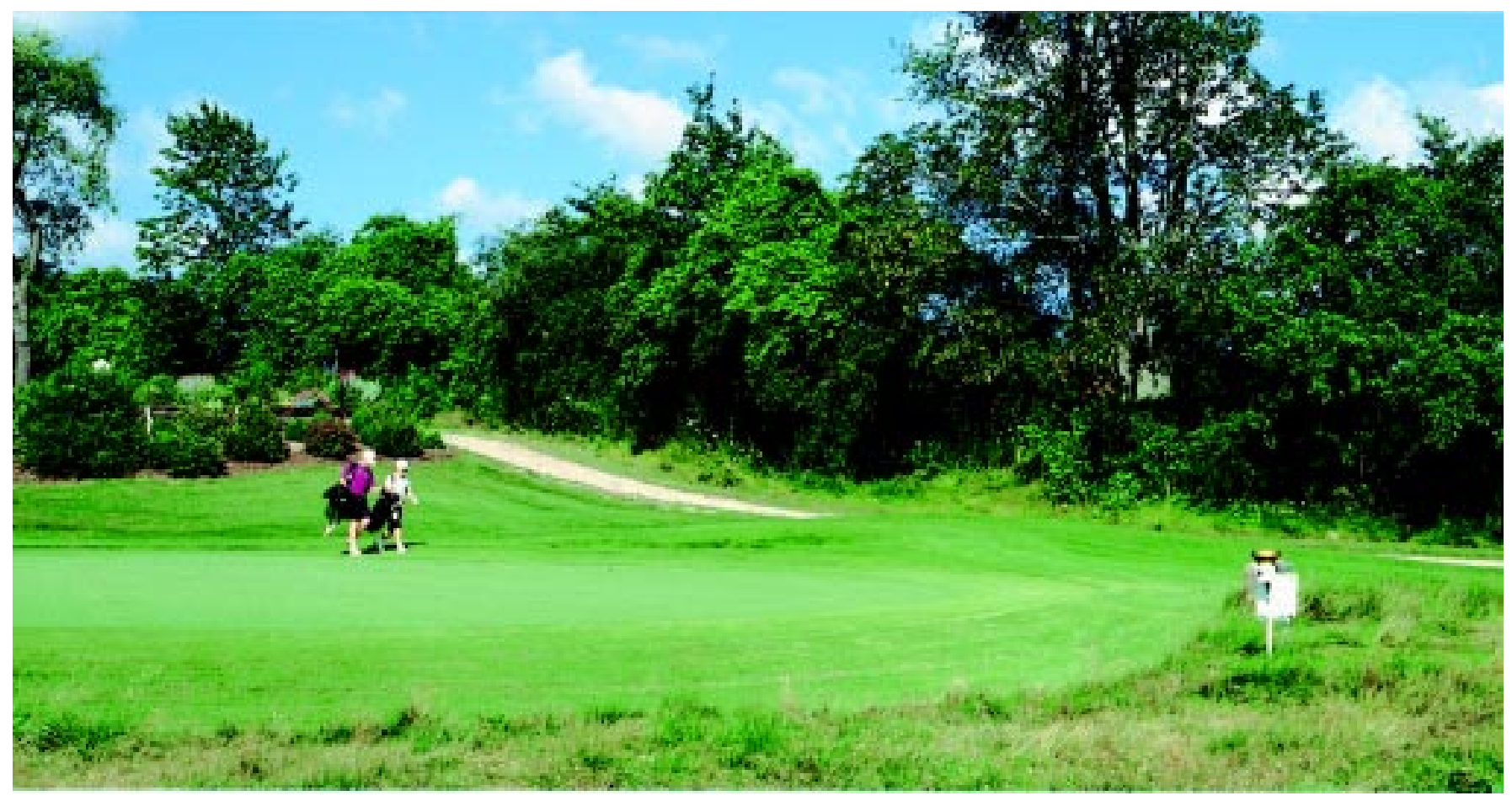

Fig. 1. Dollar spot of turfgrass reduces the aesthetic and playing quality of infected turf in recreational activities, such as golf, and can contribute to weed encroachment and plant death. An on-site electronic weather station that monitors environmental variables that influence disease severity, such as air temperature, relative humidity, and leaf wetness duration, is shown in the lower right. 
range in size from a few blades of grass to spots the size of a silver dollar (5.0- to 7.5-cm diameter) (Smith, 1955), hence the name "dollar spot" (Fig. 3) (Couch, 1995; Vargas, 1994). Necrotic patches stand out because they contrast sharply with adjacent healthy turfgrass. If disease progresses, these necrotic patches coalesce to form larger areas of necrotic, strawcolored turf (Couch, 1995; Smith, 1955). As mowing height is increased on golf course fairways, parks, and home lawns, these strawcolored patches of blighted grass range from 6 to $12 \mathrm{~cm}$ in diameter, but may coalesce to form large, irregularly shaped areas of injured turf (Couch, 1995).

In addition to symptoms of disease, mycelial growth of the pathogen also can be observed. When dew is present on leaves, or during extended periods of high relative humidity, white cobweb-like aerial mycelia of the pathogen can be seen growing on the surface of turf and extending from leaf to leaf (Monteith and Dahl, 1932; Smith, 1955). However, mycelia can also be confused with spider webs, downy seed tufts of cottonwood trees (Populus spp.) (Smiley, 1983), and mycelia of Pythium, Rhizoctonia, and Nigrospora (Smiley et al., 1992). Therefore, correct diagnosis of disease is dependent on additional information, such as climatic conditions, history of the site, management practices, and isolation of the pathogen.

\section{THE PATHOGEN}

The pathogen that causes dollar spot is currently classified as $S$. homoeocarpa; however, the taxonomic status of this causal agent remains controversial. Most authorities believe this fungus will eventually be reclassified, but difficulty in obtaining reproductive structures for study has prevented resolution of its taxonomic classification.

In 1932, Monteith and Dahl first described the symptoms of dollar spot and considered the fungus to be a Rhizoctonia sp. based on its similarity to brown patch ( $R$. solani Kühn) of turfgrass. Later, Bennett (1937) examined isolates of the pathogen recovered from diseased turf from Britain, the United States, and Australia, and categorized these isolates into three distinct strains of the fungus, described as: a) a "perfect strain" of British origin that produced ascospores and conidia; b) an "ascigerous strain" of British origin that produced ascospores and microconidia; and c) "non-sporing strains" of British, American, and Australian origin that did not produce ascospores, but did occasionally produce rudimentary apothecial initials. All three strains were considered a single fungus, despite differences among individual strains in ascospore size, and the presence of conidia or ascospores, or both. Comparisons of pathogenicity were not reported. Bennett (1937) noted that apothecia occasionally arose from small aggregates of sclerotial cells, termed "micro-sclerotia". He therefore considered the fungus to be a Sclerotinia sp. Fuckel., based on the broad definition of this genus at that time, which included fungi that produced conidia. Bennett

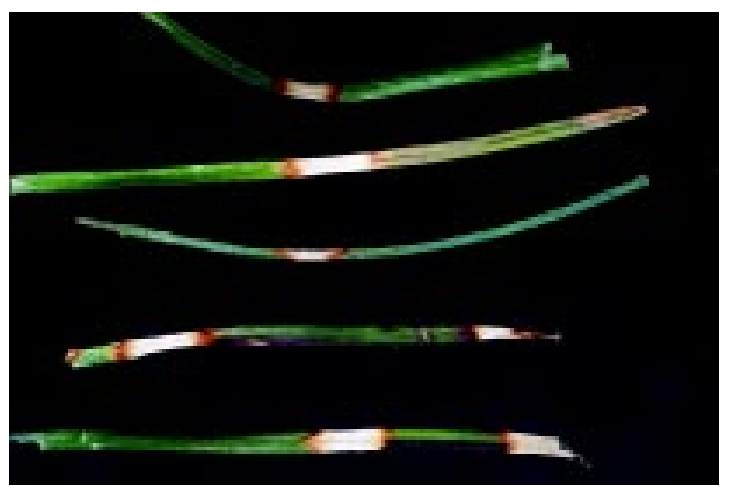

Fig. 2. Individual lesions of dollar spot, caused by Sclerotinia homoeocarpa, on Kentucky bluegrass.

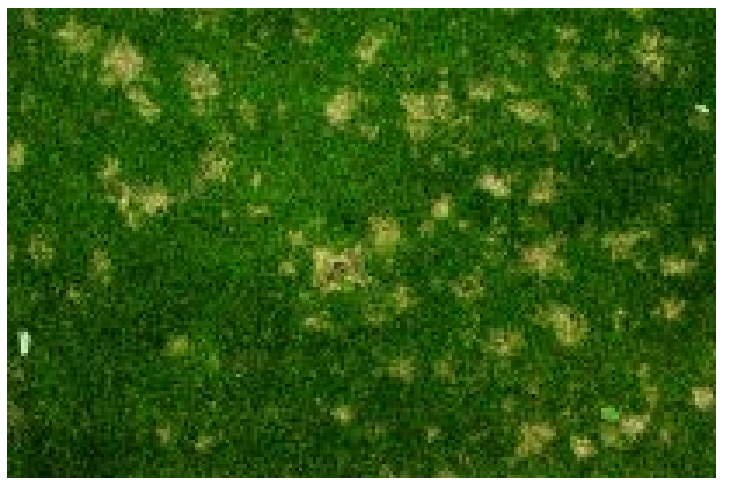

Fig. 3. Typical symptoms of dollar spot, caused by Sclerotinia homoeocarpa, on creeping bentgrass.

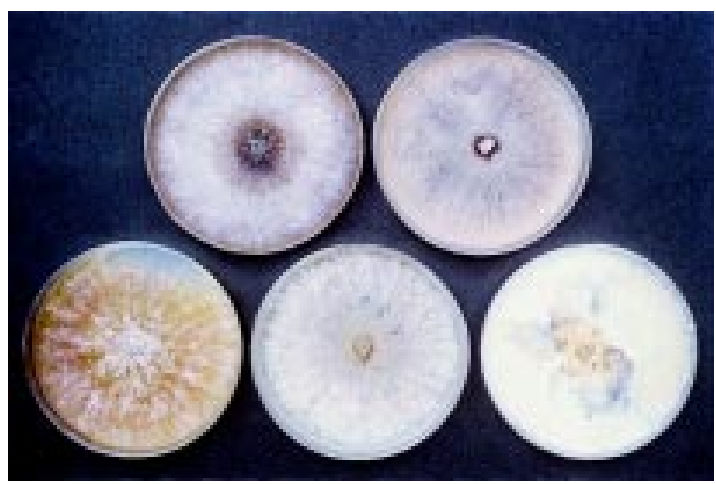

Fig. 4. Variation in culture morphology among isolates of Sclerotinia homoeocarpa, the causal agent of dollar spot.

assigned the species name homoeocarpa to these isolates because the "perfect strain" of the fungus produced cupulate or apothecialshaped structures for production of both conidia and ascospores.

The original description of $S$. homoeocarpa by Bennett (1937) can be summarized as the "perfect" strain having cupulate $(0.5-0.8 \mathrm{~mm})$ to disk- or funnel-shaped (1.0-1.5 mm) apothecia, pale cinnamon to dark brown in color, with prosenchymatic exciples, arising from microsclerotia or expansive sclerotial flakes or patches. The apothecial stalk was cylindrical, slender, flexuous, 5 to $10 \mathrm{~mm}$ long, arising singly or in clusters, simple or branched in the upper part. Asci were cylindroclavate, inoperculate, and commonly measured 150 to $165 \times$ $10.4 \mu \mathrm{m}$. Ascospores were in groups of eight, uniserate, hyaline, oblong-elliptical, biguttulate, unicellular, often developed a deli- cate median septum during germination, and commonly measured $16.0 \times 5.5 \mu \mathrm{m}$.

In 1945, Whetzel described the family Sclerotiniaceae, restricting the genus to include fungi in which the apothecium arose from a tuberoid sclerotium that was formed free on aerial mycelium. Based on these criteria, S. homoeocarpa was excluded from this family (Kohn, 1979a; Whetzel, 1945) because true sclerotia have not been found on turf affected by dollar spot (Baldwin and Newell, 1992). Bennett (1937) reported conidia were produced by the perfect strain, but other researchers have not found conidia (Baldwin and Newell, 1992; Jackson, 1973; Smith, 1955). Whetzel (1946) and Jackson (1973) considered this fungus to be either a Rutstroemia sp. or possibly synonymous with a previously described fungus, Ciboria armeriae Von Hohnel. Vargas and Powell (1997) recently 
proposed that $S$. homoeocarpa was most closely related to Rutstroemia henningsiana (Ploettn.) Dennis, and Rutstroemia cuniculi, with $88 \%$ similarity based on nuclear ribosomal internal transcribed spacer 1 sequence alignment. However, the taxonomy of Rustroemia, designated by White (1941), was deemed uncertain by Dumont and Korf (1971). Hence, the taxonomic status of this fungus was uncertain and remained as $S$. homoeocarpa.

Kohn (1979a), in a monographic revision of the genus Sclerotinia, concluded that $S$. homoeocarpa was not a true Sclerotinia sp. and, based on personal communication with Korf (Kohn, 1979a), proposed that it was more appropriately classified in Lanzia Sacc. and Moellerodiscus Henn. Furthermore, Kohn (1979b) suggested that symptoms attributed to dollar spot were caused by more than one species. If this suggestion is correct, then the correct term for dollar spot would be "dollar spot syndrome" (Jackson, 1973; Smiley, 1983).

Continued assessment of the taxonomic classification of this pathogen has been prevented by the recalcitrant nature of isolates to produce teleomorph or anamorph structures. Fertile apothecia are rarely observed in nature and cultures on artificial media (Fig. 4) often yield sterile apothecia (Baldwin and Newell, 1992; Fenstermacher, 1970; Jackson, 1973). Production of fertile apothecia by isolates of the pathogen and satisfaction of Koch's postulates are required to clarify the proper name and taxonomic position of this pathogen. Recently, fertile apothecia were reported from stromata in field samples of Festuca turf (Baldwin and Newell, 1992), and this report may stimulate renewed interest in taxonomic assessments of this pathogen. Proper taxonomic placement of the pathogen responsible for dollar spot remains unresolved (Rossman, 1987); hence, for the remainder of this review, the causal agent(s) of dollar spot is referred to as $S$. homoeocarpa.

\section{HOST RANGE}

Sclerotinia homoeocarpa can cause disease in at least 40 plant hosts, but most hosts are classified within the grass family Poaceae. Additional hosts have been reported from the Cyperaceae (sedge family), Caryophyllaceae (pink family), Convolvulaceae (morning-glory family), and the Leguminosae (pea family) (Table 1). Dollar spot in the United Kingdom is primarily confined to fescues (Couch, 1995); however, in North America, all commonly cultivated turfgrass species are susceptible to S. homoeocarpa. Although all species are considered susceptible, variations in disease severity, and the ability to recover from disease, occur among cultivars of some species (Doney et al., 1994; Hodges et al., 1975, Hsiang, 1995; Moss et al., 1995a, 1995b; Myer and Smejkal, 1995; Vincelli et al., 1997). Cultivars that are less susceptible to disease should be considered as part of an integrated disease management program. Until resistant cultivars become available, blends of turfgrass cultivars that are tolerant or resistant to prevalent dis- eases within a region are recommended for improved disease management (Schroeder and Sprague, 1994).

\section{EPIDEMIOLOGY}

Sclerotinia homoeocarpa is believed to overwinter as darkly pigmented stromata remaining on margins of dollar spot lesions from previous epidemics (Britton, 1969; Couch, 1995; Smiley et al., 1992). Fenstermacher (1980) suggested that $S$. homoeocarpa more likely survives as dormant mycelium in infected grass crowns and tissues. The pathogen primarily infects leaves via mycelial growth into cut leaf tips and stomata, but direct penetration into the leaves also occurs (Endo, 1966; Monteith and Dahl, 1932). Traditionally, conidia and ascospores were believed to be of minor importance to the spread of disease because these propagules were rarely observed in nature. However, fertile apothecia in turf swards were reported, suggesting that ascospores are a potentially important source of initial inoculum in the spring (Baldwin and Newell, 1992). Local distribution of dollar spot occurs when mycelium grows from a diseased leaf to a healthy leaf in close proximity. Over larger areas, the pathogen is distributed by physical displacement of the fungus. Humans can transport infested and diseased material, such as grass clippings, on the bottoms of golf shoes, on golf cart tires, and on maintenance equipment, such as mowers, sprayers, and irrigation hoses (Smith, 1955).

Environmental factors affect the rate of disease progress. Controlled temperature experiments revealed that the minimum, optimal, and maximum temperatures for growth of $S$. homoeocarpa were $4.5,26.8$, and $>32^{\circ} \mathrm{C}$ $\left(32{ }^{\circ} \mathrm{C}\right.$ was the highest temperature tested at which the fungus still grew), respectively, on potato dextrose agar (PDA) (Endo, 1963). Sclerotinia homoeocarpa is likely to infect and cause disease at temperatures ranging from 15 to $27^{\circ} \mathrm{C}$ (Couch, 1995; Endo, 1963), but reaches its peak growth rate and maximum pathogenicity when temperatures are between 21 and $27{ }^{\circ} \mathrm{C}$ and atmospheric humidity is $>85 \%$ (Couch, 1995; Endo, 1963). Although it does not infect roots directly, $S$. homoeocarpa has been associated with a root-damaging mycotoxin produced at temperatures $>15.5$ ${ }^{\circ} \mathrm{C}$. Culture filtrates of $S$. homoeocarpa contained a nonionic and heat-stable chemical that caused creeping bentgrass roots to cease growth, thicken, and turn brown in color (Malca and Endo, 1965). Baldwin and Newell (1992) found that ascospores were released from fertile apothecia after incubation at $21^{\circ} \mathrm{C}$ with a 12-h light cycle for $48 \mathrm{~h}$, and ascospores germinated in water within $24 \mathrm{~h}$ at $20^{\circ} \mathrm{C}$. There is considerable variability in response to environmental conditions among isolates of S. homoeocarpa recovered from various locations (Bennett, 1937; Endo, 1963; Freeman, 1967). In general, variants of dollar spot are active from late spring to autumn when days are warm and humid with nights that result in heavy dew (Smiley et al., 1992).

\section{CULTURAL CONTROLS}

Cultural practices can be very effective for the management of dollar spot in turf. Most fungi require free water on the leaf surface to infect; therefore, the amount and duration of leaf wetness is an important factor in dollar spot occurrence (Williams et al., 1996). Williams (1993) found that dew displacement on turfgrasses reduced leaf wetness duration by several hours. To minimize the dew period, the following practices have been suggested: pole, syringe, and mow turf in early morning to remove water, and prune or remove trees and shrubs to increase air circulation and solar radiation so dew dries more quickly. In addition to rain, evening irrigation, and dew, guttation fluid also contributes to water on the leaf surface (Vargas, 1994; Williams, 1996). Exudates from creeping bentgrass (Agrostis palustris Huds.) constituted about one-third of the dew accumulation and contained sugars and amino acids that served as a nutrient source for the fungus (Williams, 1996).

Moisture stress can also predispose turf to dollar spot. Turfgrass suffering from moisture stress in greenhouse studies was more susceptible to disease (Couch and Bloom, 1960) and, as a result, there may be a higher prevalence of dollar spot during dry seasons. A heavy thatch layer contributes to low soil moisture because it inhibits water penetration into soil. Irrigation to maintain soil moisture content above $75 \%$ of field capacity will reduce disease severity (Couch, 1995). A lack of sufficient nitrogen $(\mathrm{N})$ fertilizer will predispose foliage to dollar spot infection and disease severity (Endo, 1966; Freeman, 1969; Watkins and Wit, 1995). Sclerotinia homoeocarpa requires an available food base for growth and appressorium formation; thus, plants that are $\mathrm{N}$ stressed are more likely to develop senescent foliage that is more susceptible to infection than plants receiving adequate $\mathrm{N}$ (Endo, 1966). Applications of $\mathrm{N}$ can be used to suppress dollar spot (Cook et al., 1964; Markland et al., 1969) because $\mathrm{N}$-supplemented grass grows more quickly; therefore, more frequent mowing removes necrotic tissue during times when microclimate is less favorable for growth of the fungus (Couch, 1995). Collection and disposal of clippings removes secondary inoculum and may result in less disease. Markland et al. (1969) proposed that vigorous plant growth reduced disease severity caused by $S$. homoeocarpa. Subsequently, Landschoot and McNitt (1997) demonstrated that disease suppression was positively correlated with darkgreen turf, indicating that as $\mathrm{N}$ availability increased, disease severity decreased. Applications of readily available $\mathrm{N}$, in the form of ammonium nitrate and sewage sludge, effectively suppressed disease (Cook et al., 1964; Markland et al., 1969). Activated sewage sludge provided the greatest suppression, and also caused an increase in concentrations of iron, copper, and zinc in plant foliage. Markland et al. (1969) suggested that levels of these heavy metals in plant tissue were large enough to inhibit a fungal pathogen. The key to managing disease through $\mathrm{N}$ fertilization is mod- 
Table 1. Known hosts of Sclerotinia homoeocarpa.

Scientific name
Caryophyllaceae (= Alsinaceae): Pink family
Sagina procumbens L. ${ }^{\mathrm{y}}$

Sagina procumbens L. ${ }^{\mathrm{y}}$

Convolvulaceae: Morning-glory family ${ }^{\mathrm{x}}$

Dichondra repens J.R.Forst. \& G. Forst. $=$ D. micrantha

Cyperaceae: Sedge family

Cyperus esculentus L. ${ }^{y}$

Cyperus rotundus $\mathrm{L}$.

Carex sp. L.

Leguminosae (= Fabaceae): Pea family ${ }^{\mathrm{x}}$ Arachis glabrata Benth. ${ }^{w}$

Poaceae (= Gramineae): Grass family Agrostis sp. L.

Agrostis alba $\mathrm{L} .^{\mathrm{y}}$

Agrostis canina L.

Agrostis palustris Huds. ${ }^{v}$

Agrostis stolonifera L.

Agrostis tenuis (L.) Sibth. ${ }^{\vee}$

Cynodon dactylon (L.) Pers. ${ }^{\mathrm{y}}$

Cynodon incompletus var. hirautus deWet et Harlanw

Cynodon magennisii Hurcombe ${ }^{w}$

Cynodon transvaalensis Burtt-Davy

Digitaria didactyla Willd.

Digitaria ischaemum (Schreb.) Muhl. y

Eremochloa ophiuroides(Munro.) Hack.

Festuca sp. L.

Festuca elatior L. =

Festuca arundinacea Schreb.

Festuca ovina $\mathrm{L} .=$ F. saximontana $\mathrm{Rydb}$.

Festuca ovina var. duriuscula (L.) Koch

Festuca rubra L.

Festuca rubra var. commutata Gaud.-Beaup. = Festuca fallax Thuill.

Holcus lanatus L.

Common name

Reference

Pearlwort

Birdseye

Mercury bay weed

Nutsedge

Sedge

Perennial peanut

Bentgrass

Redtop

Velvet bentgrass

Creeping bentgrass

Colonial bentgrass

New Zealand browntop

Rhode Island bentgrass

Coastal Bermudagrass

Wiregrass

Bermudagrass

Bermudagrass

Magennis Bermudagrass

Bermudagrass

African Bermudagrass

Transvaal dogtooth grass

Blue couch grass

Smooth crabgrass

Centipede grass

Fescue

English bluegrass ${ }^{w}$

Tall fescue

Reed fescue

Alta fescue

Sheep fescue

Hard fescue ${ }^{\mathrm{w}}$

Red fescue

Chewing fescue

Common velvet grass

Yorkshire fog
Fenstermacher, 1970

Boesewinkel, 1977

Bain, 1964

Whetzel, 1946

Hoover \& Kucharek, 1995

Bennett, 1937; as cited by Smith, 1955

Beard, 1973; Britton, 1969; Couch, 1995; Sprague, 1950; U.S. Dept. of Agriculture, 1960

Beard, 1973; Britton, 1969; Couch, 1995;

Fenstermacher, 1970; Smith, 1959; Sprague, 1950;

U.S. Dept. of Agriculture, 1960

Beard, 1973; Britton, 1969; Couch, 1995,

Fenstermacher, 1970; Smith, 1955; Smith, 1959;

Sprague, 1950; U.S. Dept. of Agriculture, 1960

Britton, 1969; Boesewinkel, 1977; Couch, 1995; Smith, 1955; Smith, 1959; Sprague, 1950; U.S. Dept. of Agriculture, 1960

Bain, 1962; Beard, 1973; Britton, 1969; Couch, 1995; Fenstermacher, 1970; Freeman, 1967

Beard, 1973

Beard, 1973

Beard, 1973

Simmonds, 1958

Fenstermacher, 1970

Beard, 1973; Britton, 1969; Couch, 1995; Freeman, 1967

Bennett, 1937; as cited by Smith, 1955

Couch, 1995

Britton, 1969; Couch, 1995; Smith, 1959; Sprague, 1950

Hodges et al., 1975

Beard, 1973; Boesewinkel, 1977; Britton, 1969; Couch, 1995; Fenstermacher, 1970; Hodges et al., 1975; Smith, 1955

Hodges et al., 1975; Smith, 1955

Couch, 1995; Smith, 1955 
Table 1. Continued.

\begin{tabular}{|c|c|c|}
\hline Scientific name & Common name & Reference \\
\hline $\begin{array}{l}\text { Lolium multiflorum Lam. = } \\
\quad \text { Lolium italicum }\end{array}$ & $\begin{array}{l}\text { Italian ryegrass } \\
\text { Australian ryegrass }\end{array}$ & Britton, 1969; Freeman, 1967 \\
\hline Lolium perenne $\mathrm{L}$. & $\begin{array}{l}\text { Perennial ryegrass } \\
\text { Annual ryegrass }\end{array}$ & Wilkinson et al., 1975 \\
\hline Paspalum notatum Flügge. & Bahia grass & $\begin{array}{l}\text { Bain, 1962; Beard, 1973; Britton, 1969; Couch, 1995; } \\
\text { Fenstermacher, 1970; Freeman, 1967; Gudauskas and } \\
\text { McGlohon, } 1964\end{array}$ \\
\hline Poa sp. L. & Bluegrass & Bennett, 1937; as cited by Smith, 1955 \\
\hline Poa aпnua $\mathrm{L}$. & $\begin{array}{l}\text { Annual bluegrass } \\
\text { Speargrass } \\
\text { Low bluegrass } \\
\text { Six weeks grass } \\
\text { Dwarf meadow grass }\end{array}$ & $\begin{array}{l}\text { Beard 1973; Boesewinkel, 1977; Britton, 1969; Couch, } \\
\text { 1995; Sprague, 1950; U.S. Dept. of Agriculture, } 1960\end{array}$ \\
\hline Poa arachnifera Torr. & Texas bluegrass & U.S. Dept. of Agriculture, 1960 \\
\hline Poa arida Vasey $^{\mathrm{y}}$ & Plains bluegrass & U.S. Dept. of Agriculture, 1960 \\
\hline Poa pratensis L. & $\begin{array}{l}\text { Kentucky bluegrass } \\
\text { June grass } \\
\text { Spear grass }\end{array}$ & $\begin{array}{l}\text { Beard, 1973; Britton, 1969; Couch, 1995; Fenstermacher, } \\
\text { 1970; Smith, 1955; Sprague,1950; Wilkinson et al., 1975; } \\
\text { U.S. Dept. of Agriculture, } 1960\end{array}$ \\
\hline Poa trivialis L. & $\begin{array}{l}\text { Rough bluegrass } \\
\text { Rough-stalk bluegrass } \\
\text { Rough-stalk meadow grass }\end{array}$ & Smith, 1959 \\
\hline $\begin{array}{l}\text { Puccinellia maritima } \\
\text { (Hudson) Parl. }{ }^{\mathrm{y}}\end{array}$ & Seaside alkali-grass & Halcrow, 1965 \\
\hline $\begin{array}{l}\text { Stenotaphrum secundatum } \\
\text { (Walt.) O. Kuntze }\end{array}$ & St. Augustinegrass & Beard, 1973; Britton, 1969; Freeman, 1967 \\
\hline Zoysia japonica Steud. & $\begin{array}{l}\text { Zoysia grass }{ }^{\mathrm{w}} \\
\text { Korean or Japanese lawngrass }\end{array}$ & Beard, 1973; Britton, 1969; Couch, 1995 \\
\hline Zoysia matrella (L.) Merrill. & $\begin{array}{l}\text { Manila grass } \\
\text { Zoysia grass } \\
\text { Japanese carpet grass }\end{array}$ & Beard, 1973 \\
\hline $\begin{array}{l}\text { Zoysia tenuifolia Willd. } \\
\text { ex. Trin. }\end{array}$ & $\begin{array}{l}\text { Muscarene grass }{ }^{\mathrm{v}} \\
\text { Korean velvet grass }\end{array}$ & Beard, 1973; Couch, 1995 \\
\hline
\end{tabular}

eration (Fenstermacher, 1980), because insufficient fertilization will lead to dollar spotsusceptible turfgrass and excessive fertilization can promote other diseases.

\section{FUNGICIDES AND FUNGICIDE RESISTANCE}

During the last 40 years, fungicides have been the most successful tool for managing dollar spot. Often, numerous applications of fungicides are required to maintain diseasefree turf throughout a growing season and, as a result, resistance of $S$. homoeocarpa to fungicides has posed an ongoing challenge to the turfgrass industry. Resistance to heavy metalbased fungicides (Cole et al., 1968; Massie et al., 1968), benzimidazoles (Cole et al., 1974; Detweiler et al., 1983; Goldberg and Cole, 1973; Warren et al., 1974), anilazine (Nicholson et al., 1971), dicarboximides
(Detweiler et al., 1983), and demethylation inhibitors (DMIs) (Golembiewski et al., 1995) has been reported from various regions throughout the United States. To compound this problem, strains of $S$. homoeocarpa that are resistant to one fungicide are often crossresistant to other fungicides that share the same mechanism of action (Cole et al., 1974; Golembiewski et al., 1995; Warren et al., 1974).

From the 1940 s to the mid-1960s, cadmium-based fungicides were used for dollar spot management with excellent results (Fenstermacher, 1980). By the late 1960s, however, several cases of cadmium tolerance were reported, and tolerance of S. homoeocarpa to mercuric fungicides also became widespread (Cole etal., 1968; Fenstermacher, 1980; Massie et al., 1968; Smith et al., 1989). Cadmiumtolerant strains became predominant and remained after cadmium fungicide applications ceased, indicating that they possessed increased fitness (Warren et al., 1977). Once resistance developed, these fungicides continued to be ineffective against the pathogen, even if temporarily removed from the management program (Warren et al., 1977).

When first introduced in the late 1960s, the benzimidazole-type systemic fungicides provided excellent disease control at low dosages. However, resistant biotypes of the pathogen emerged relatively quickly (Fenstermacher, 1980; Smith et al., 1989; Vargas, 1994). Warren et al. (1977) demonstrated that the benzimidazole-resistant strains collected from the eastern and midwestern United States were less fit in fungal populations of the pathogen, and that populations would revert to the wildtype after discontinuation of benzimidazole application. In contrast, Vargas (1994) stated that tolerant strains were more fit and dominated wild-type populations long after appli- 
cation ceased. Increases in disease severity resulted when creeping bentgrass colonized with a strain of benzimidazole-resistant $S$. homoeocarpa was treated with this group of fungicides (Couch and Smith, 1991).

Resistance of S. homoeocarpa to DMI fungicides was reported 11 years after the introduction of this family of fungicides for management of dollar spot in the United States (Doney and Vincelli, 1993; Golembiewski et al., 1995; Vargas et al., 1992). These fungicides were registered for use on turfgrass in Canada in 1994; however, prior to registration one isolate of $S$. homoeocarpa found in Ontario had reduced DMI sensitivity (Hsiang et al., 1997a). Resistance probably became a problem in Canada because of transportation of isolates across the border, or from nonlabel use of the fungicides (Hsiang et al., 1997a). Hsiang et al. (1998) found that there was a slight fitness cost for resistant isolates, which supports the recommendation that DMI fungicides not be used when the incidence of dollar spot is severe, or in consecutive years (Golembiewski et al., 1995; Vargas et al., 1992). This strategy reduces selection pressure on wild-type populations of the pathogen, allowing them to remain dominant in the population.

The occurrence of pesticide resistance among populations of $S$. homoeocarpa is compounded by the development of multiple-resistance to fungicides in various families. Benzimidazole-resistant strains with resistance to cadmium (Warren et al., 1974, 1977) or dicarboximides (Detweiler et al., 1983) have been reported. Some DMI-resistant strains have been found that are multiresistant to benzimidazole and dicarboximide fungicides (Golembiewski et al., 1995; Vargas et al., 1992). Although resistance was more likely to occur in isolates that already possessed resistance to another fungicide group, pathogen strains that were double- or multiresistant to dicarboximides did not persist in turf once use of that group of fungicides was discontinued (Vargas, 1994; Vargas et al., 1992). However, strains with benzimidazole and DMI resistance were persistent (Vargas, 1994).

Fungicides are applied to turfgrass at regular intervals, but with an accurate diseaseforecasting model, fungicides could be applied only when weather conditions are favorable for fungal activity, thereby reducing selection pressure for resistant strains of the pathogen. Recommendations for chemical application have often emphasized the use of tank mixes of fungicides with different modes of action (Urech, 1988). This strategy is believed to provide effective disease control while reducing the risk of developing fungicideresistant pathogen biotypes (Couch, 1995). Sanders et al. (1985) reported that half-rate (14.2 g product per $93 \mathrm{~m}^{2}$ ), two component mixtures of benzimidazoles, dicarboximides, and sterol biosynthesis inhibitors provided excellent suppression of dollar spot on creeping bentgrass. Reduced-rate fungicide applications may also reduce selection pressure for the development of resistance.

Fungicides can also have direct and indi- rect effects on nontarget microorganisms (Smiley and Craven, 1979) and these effects may influence the development of diseases such as dollar spot. Significant increases in disease severity following the termination of fungicide treatments may be related to such effects (Melzer and Boland, 1998).

\section{BIOLOGICAL CONTROL}

Several biological control strategies for management of dollar spot have been investigated and, in general, these strategies fall into two approaches. One approach is through the application of nutrients and organic amendments to stimulate naturally occurring populations of microorganisms in the phyllosphere. The second approach is the more typical use of innundative applications to turf of specific bacteria and fungi known to suppress disease. Most biological control strategies evaluated to date have been less effective than fungicides, but several merit further investigation.

\section{Nutrients and organic amendments}

Several studies compared the influence of organic amendments, such as commercially available organic fertilizers, composts, and sludges, on suppression of dollar spot (Hoyland and Landschoot, 1993; Landschoot and McNitt, 1997; Liu et al., 1995; Nelson and Craft, 1991a). Several composts suppressed dollar spot severity but there was substantial variation in their efficacy. In one study, the organic fertilizer Ringer Compost Plus (Ringer CP) (Ringer Corp., Minneapolis) provided substantially greater disease suppression than treatment with iprodione [3-(3,5-dichlorophenyl)$\mathrm{N}$-(1-methylethyl)-2,4-dioxo-1-imidazolidine carboxamide] (Nelson and Craft, 1991a). Effective disease suppression was evident up to 1 month following application of Ringer CP and the organic fertilizer Ringer Greens Restore (Nelson and Craft, 1992). However, 1 month after a second application, propiconazole $\{1-[(2-(2,4-$ dichlorophenyl)-4-propyl1,3-dioxolan-2-yl)methyl]-1H-1,2,4-triazole \} was more effective than the organic fertilizers. Some disease suppression resulted from applications of sludge composts and of Sustane turkey litter compost (Sustane Corp., Cannon Falls, Minn.) (Nelson and Craft, 1992; Soika and Sanders, 1991). In contrast, Hoyland and Landschoot (1993) found little suppression of disease by Ringer CP, with effects comparable to applications of a high rate of Sustane. The organic fertilizers, Harmony/KLM and Ringer Commercial Greens Super, and the synthetic fertilizers, urea and Nitroform, provided similar levels of disease suppression (Hoyland and Landschoot, 1993). Landschoot and McNitt (1997) demonstrated that organic fertilizers, such as Ringer Commercial Greens Super, Ringer CP, Sustane, Milorganite, and Harmony, were not superior in dollar spot suppression when compared with synthetic $\mathrm{N}$ sources, such as urea. Further studies are required to define whether reduction in dollar spot is attributed to a microbial effect on the pathogen or increased vigor of the plant in response to $\mathrm{N}$ amendments (Landschoot and McNitt, 1997).

Despite the efficacy of several of these organic amendments, no information was provided on mechanisms of action. Markland et al. (1969) found no correlations between disease reduction by the treatments and microbial activity, soil pH, or fertility. Liu et al. (1995), however, established that the ability of selected organic amendments to suppress disease was correlated with increased populations of naturally occurring microorganisms in turf. For example, treatment of a creeping bentgrass putting green with Ringer Turf Restore and Ringer Greens Super substantially suppressed dollar spot incidence (Liu et al., 1995) and significantly increased populations of soil microorganisms. Plots of creeping bentgrass treated with Ringer amendments or ammonium nitrate had higher fungal and bacterial populations on grass, thatch, and soil than plots treated with other organic amendments or the untreated control. According to Lui et al. (1995), these higher microbial populations resulted from increased plant growth in response to the fertilizer $\mathrm{N}$ content, the introduction of microorganisms in the treatments, the stimulation of native microbe populations, or combinations of these factors.

Topdressings of other organic materials, such as autoclaved grain previously colonized by Fusarium heterosporum Nees:Fr. (teleomorph: Gibberella gordonia Booth) (Goodman and Burpee, 1991), wheat-bran (Triticumaestivum L.) (Schumann and Reuter, 1993), autoclaved sand-oatmeal (Avena sativa L.), and sodium alginate-oatmeal formulations (Zhou and Boland, 1998b), suppressed dollar spot when included as experimental controls in evaluations of biological control agents (BCAs). In each of these experiments, the authors reported reduced disease severity in plots treated with organic substrates that did not contain live organisms (e.g., formulation control) in comparison with plots receiving no treatments whatsoever (i.e., experimental control). Results such as these may support the suggestion that stimulation of naturally occurring microbial populations by sterile amendments is related to disease suppression. Alternative mechanisms may also contribute to this effect, such as growth stimulation by nutrients in organic materials or the presence of antimicrobial metabolites in heat-killed, colonized substrates.

\section{Microbial antagonists}

Inundative applications of bacteria and fungi known to suppress dollar spot have been investigated, with varying degrees of success. Topdressings prepared from cornmeal-sand (Zea mays L.) mixtures inoculated with strains of Enterobacter cloacae (Jordan) Hormaeche and Edwards were used to introduce this bacterial antagonist into creeping bentgrass putting greens naturally infested with $S$. homoeocarpa (Nelson and Craft, 1991b). In the first year, monthly applications of isolate EcCT-501 were as effective as curative rates of propiconazole in reducing disease severity. 
However, the following year, the same isolate provided a lower and less persistent suppression of disease. Another isolate provided variable disease suppression in both years, but was the only treatment to provide significant suppression on the second rating date in the second year. The mechanisms of action responsible for disease suppression were not determined, but this test was performed on 60-yearold swards believed to possess a diverse and well-established microflora that restricted the activity of E. cloacae. The authors suggested that this antagonist could be more effective on newer putting greens with a less diverse microflora, as competition would be reduced between the naturally occurring and artificially introduced microbial populations.

Topdressings of wheat-bran fortified with a Streptomyces sp. were evaluated for their ability to suppress dollar spot on a creeping bentgrass putting green, but the results were inconclusive (Schumann and Reuter, 1993). There was no correlation between total actinomycete population and application of sterile bran or Streptomyces-infested bran. Either the application method did not increase the isolate population, or the method of sampling turfgrass and soil cores did not provide an accurate assessment of the populations present.

Several microorganisms have been identified that are capable of producing antifungal compounds that suppress development of $S$. homoeocarpa. Strains of Pseudomonas fluorescens Migula and one strain of $P$. lindbergii (ATCC 31099) suppressed dollar spot on Kentucky bluegrass (Poa pratensis L.) under controlled conditions (Hodges et al., 1994; Rodriguez and Pfender, 1997). Antagonism to $S$. homoeocarpa in creeping bentgrass and bluegrass turf and grass clippings by $P$. fluorescens was associated with pyrrolnitrin, an antibiotic produced by the bacterium (Rodriguez and Pfender, 1997). In a 2-year field study, $F$. heterosporum suppressed dollar spot symptoms by up to $93 \%$ (Goodman and Burpee, 1991). Treated plots continued to show residual effects of the BCA treatments into the following summer. Disease suppression by the BCA topdressings was attributed to inhibition of pathogen growth by antibiosis. This view was supported by topdressing with heat-killed $F$. heterosporum, which provided disease suppression comparable with that of topdressings that had not been heat-killed. In addition, in vitro tests confirmed that inhibitory or toxic compounds were released by $F$. heterosporum.

The efficacy of $F$. heterosporum in suppressing dollar spot of turf was compared in a 2-year field study with several other fungal antagonists of Sclerotinia spp., such as Alternaria sp., Cladosporium sp., and Epicoccum sp. (Boland and Smith, 1992). None of these fungi were as effective as the fungicide iprodione, nor were they effective under high disease pressure. Fusarium heterosporum was the most effective BCA and suppressed disease by $32 \%$ to $49 \%$. The efficacy of this BCA could be increased by modifications in formulation, concentration of the BCA applied, the frequency of applica- tion, and the use of weather-predicted applications.

Other microorganisms that have been identified as antagonists of $S$. homoeocarpa include Rhizoctonia sp., Acremonium sp. (Goodman and Burpee, 1991), Gliocladium virens Miller, Giddens and Foster (Haygood and Mazur, 1990), Trichoderma hamatum (Bonord.) Banier strain 382, and Flavobacterium balustinum Harrison strain $299 \mathrm{r}_{2}$ (Grebus et al., 1995). Although applications of these BCAs provided good dollar spot suppression, studies that included a fungicide treatment often achieved greater control.

Trichoderma harzianum Rifai is a bioprotectant that has been tested against numerous fungal plant pathogens (Lo et al., 1996, 1997). Trichoderma harzianum strain T22 (KRLAG2) was recently registered with the U.S. Environmental Protection Agency as a biological fungicide for control of fungal diseases of turf, including dollar spot (BioWorks, Inc., Geneva, N.Y.). Marketed as BIO-TREK (Wilbur-Ellis, Fresno, Calif.), this bioprotectant is the first biological fungicide approved for turf in the United States. When introduced into turf, strain T-22B rapidly colonizes the roots of plants, protecting them through competition with, and mycoparasitism of, the pathogen. However, this product is only effective when applied as a preventive measure. Once a pathogen penetrates the plants and disease symptoms are apparent, an appropriate fungicide must be applied. Efficacy studies of $T$. harzianum have yielded conflicting results (Lo et al., 1996, 1997; Melzer and Boland, 1998; Vincelli and Doney, 1997; Vincelli et al., 1996); therefore, further research is required to improve the consistency of this biological control agent.

Hypovirulence refers to the reduced ability of a pathogen to infect, colonize, kill, and reproduce on susceptible host tissue (Elliston, 1982). Hypovirulence is often associated with the presence of double-stranded RNA (dsRNA), which is transmissible between infected and healthy isolates of the pathogen. The use of "transmissible hypovirulence" to suppress plant disease was reported for several plant pathogens (Anagnostakis, 1982; Elliston, 1982; Herr, 1995) and transmissible hypovirulence associated with dsRNA also was reported from $S$. homoeocarpa (Zhou and Boland, 1997, 1998b). In growth room conditions, three hypovirulent isolates of $S$. homoeocarpa suppressed disease by $51 \%$ to $90 \%$ (Zhou and Boland, 1998b). In artificially infested field plots, the hypovirulent isolate suppressed disease by up to $80 \%$ and disease suppression was significant for 1 year postinoculation. In naturally infested field plots, the hypovirulent isolate suppressed disease by up to $58 \%$ and, in most plots, disease suppression was equivalent to treatment with chlorothalonil (tetrachloroisophthalonitrile). Although further epidemiological and efficacy studies need to be conducted, this study demonstrates that hypovirulent isolates have potential as an effective management tool for the control of dollar spot and other Sclerotinia-incited diseases (Zhou and Boland, 1998a).
The current status of biological control of turfgrass diseases can best be summarized as an emerging technology. Biological control agents are currently in various stages of research and development, but the recent registration of BIO-TREK is an encouraging sign that such products are becoming more commercially viable and available. Integration of BCAs into integrated disease management programs will provide the turf industry with alternatives to chemical fungicides, and perhaps an effective tool to prevent the development and spread of fungicide-resistant strains.

\section{DISEASE FORECASTING}

Presently, fungicide and biological control treatments for dollar spot are applied to turf at regular intervals. In some crops, diseases can be forecast using disease prediction models that correlate weather conditions with sporulation, infection, or symptom expression (Gillespie and Sutton, 1979; Gleason et al., 1995; Madden et al., 1978). Turf disease forecasters for anthracnose [Colletotrichum graminicola (Ces.) G.W. Wils.] of annual bluegrass (Danneberger et al., 1984); Rhizoctonia blight $(R$. solani) of creeping bentgrass (Schumann et al., 1994); brown patch ( $R$. solani) of perennial ryegrass (Lolium perenne L.) (Fidanza et al., 1996); and Pythium blight on turfgrass (Nutter et al., 1983) have been developed. In general, environmental variables, such as leaf wetness, relative humidity, rainfall, temperature, and solar radiation, are monitored until conditions are conducive to pathogen development, and a fungicide is then applied. Fungicide use is minimized because treatments are applied only when conditions are favorable for disease, and are not applied when disease is unlikely. The development of an accurate model to predict dollar spot also would be applicable for weather-timed applications of microbial antagonists (Boland and Smith, 1992; Goodman and Burpee, 1991).

Disease forecasting systems for dollar spot were proposed by Mills and Rothwell (1982) and Hall (1984). In the Mills and Rothwell (M\&R) system, a fungicide application was recommended when maximum air temperature was $\geq 25{ }^{\circ} \mathrm{C}$ and maximum relative humidity was $\geq 90 \%$ during any $3 \mathrm{~d}$ of a $7-\mathrm{d}$ period. In the Hall system, a fungicide application was recommended after 2 consecutive days of rainfall and a mean air temperature of $\geq 22{ }^{\circ} \mathrm{C}$, or 3 consecutive days of rainfall and a mean air temperature of $\geq 15^{\circ} \mathrm{C}$. The accuracy of these two disease forecasters was compared in a 2-year study, but both models failed to predict weather-related increases of dollar spot (Burpee and Goulty, 1986). The M\&R model predicted too many infection periods, and disease suppression resulted more from the high frequency of prediction-based fungicide applications and not the accuracy of the model. The Hall system failed to predict sufficient infection periods, resulting in poor disease control. Boland and Smith (1998) used a preliminary dollar spot forecasting model in the EnviroCaster (NEOGEN Corp., Lansing, Mich.) to time applications of biological agents. 
The model did not predict any infection periods during 1991, despite high levels of disease in all plots.

The M\&R and Hall models used easily measured variables to predict disease. The Hall system used rainfall and air temperature data recorded at a weather station located 2.2 $\mathrm{km}$ from the research station and did not include irrigation inputs. Neither model accounted for leaf wetness caused by dew and guttation, both of which are important contributors to water on the leaf surface (Williams, 1996). Although humidity and rainfall are factors in dew formation, actual leaf wetness duration is a more accurate indicator of available free water. Today, data are available from commercial weather stations capable of measuring numerous turf microclimate variables, and many golf course superintendents have their own weather stations (Fig. 1). With this new technology in place, an advanced weather model is needed that incorporates more turfgrass microclimate variables to accurately predict dollar spot.

\section{CONCLUSIONS AND RECOMMENDATIONS FOR RESEARCH}

In summary, dollar spot is one of the most common and destructive diseases of warmand cool-season turfgrasses in North America. Symptoms of disease include 5- to 7-cm-diameter spots of straw-colored turfgrass on closely mown putting greens and tees, or large coalescing spots on lawns and turfgrasses maintained at higher mowing heights. Although the pathogen is commonly referred to as $S$. homoeocarpa, the taxonomic status of this fungus requires clarification. The epidemiology of disease is associated with warm temperatures and heavy, prolonged periods of dew in summer and early fall, but an improved understanding of environmental and physical factors contributing to disease will contribute to better disease management strategies.

Currently, disease is primarily controlled through fungicides and by cultural practices. With the onset of fungicide resistance in populations of the pathogens and heightened public awareness concerning the use of pesticides, there is increasing need for alternative pest management practices and technologies. Biological control of dollar spot has shown promising results in laboratory, greenhouse, and field evaluations. However, biological control is still largely an emerging technology, despite the recent registration of a strain of $T$. harzianum in the United States for managing several turf diseases. Turf amendments containing microorganisms and $\mathrm{N}$ have shown promise for management of dollar spot; however, the contribution of microbes or N, or both, to disease suppression requires clarification.

Previous disease prediction models have not been effective for predicting the need for fungicide applications. Therefore, a more accurate disease prediction model is needed. The development of an accurate dollar spot forecasting model would contribute to reduced fungicide resistance and costs, and perhaps increase the effectiveness of applied BCAs. Further research on the biology, epidemiology, taxonomy, and potential microbial antagonists of $S$. homoeocarpa is required to achieve cost-effective and environmentally sound management of dollar spot.

\section{Literature Cited}

Anagnostakis, S.L. 1982. Biological control of chestnut blight. Science 215:466-471.

Bailey, L.H. and E.Z. Bailey. 1976. Hortus third. MacMillian, New York.

Bain, D.C. 1962. Sclerotinia blight of bahia and coastal bermuda grasses. Plant Dis. Rptr. 46:5556.

Bain, D.C. 1964. Sclerotinia blight on nutgrass in Mississippi. Plant Dis. Rptr. 48:742.

Baldwin, N.A. and A.J. Newell. 1992. Field production of fertile apothecia by Sclerotinia homoeocarpa in Festuca turf. J. Sports Turf. Res. Inst. 68:73-76.

Beard, J.B. 1973. Turfgrass: Science and culture. Prentice-Hall, Englewood Cliffs, N.J.

Beard, J.B. and R.L. Green. 1994. The role of turfgrasses in environmental protection and their benefits to humans. J. Environ. Qual. 23:452460.

Bennett, F.T. 1937. Dollar spot disease on turf and its causal organism Sclerotinia homoeocarpa $\mathrm{n}$. sp. Ann. Appl. Biol. 24:236-257.

Boesewinkel, H.J. 1977. New plant disease records in New Zealand: Record in the period 1969-76. New Zealand J. Agr. Res. 20:583-589.

Boland, G.J. and E.A. Smith. 1992. Biological control of dollar spot of turfgrass. Guelph Turfgrass Inst. Annu. Res. Rpt. Guelph, Ont., Canada. p. 106-109.

Brako, L., A.Y. Rossman, and D.F. Farr. 1995. Scientific common names of 7000 vascular plants in the United States. Amer. Phytopath. Soc., St. Paul, Minn.

Britton, M.P. 1969. Turf grass diseases, p. 288-329. In: A.A. Hanson and F.V. Juska (eds.). Turfgrass science. Amer. Soc. Agron., Madison, Wis.

Burpee, L.L. and L.G. Goulty. 1986. Evaluation of two dollarspot forecasting systems for creeping bentgrass. Can. J. Plant Sci. 66:345-351.

Cole, H., B. Taylor, and J. Duich. 1968. Evidence of differing tolerances to fungicides among isolates of Sclerotinia homoeocarpa. Phytopathology 58:683-686.

Cole, H., Jr., C.G. Warren, and P.L. Sanders. 1974. Fungicide tolerance-A rapidly emerging problem in turfgrass disease control. Proc. 2nd Intl. Turfgrass Res. Conf. 2:344-349.

Cook, R.N., R.E. Engel, and S. Bachelder. 1964. A study of the effect of nitrogen carriers on turfgrass disease. Plant Dis. Rptr. 48:254-255.

Couch, H.B. 1995. Disease of turfgrasses. 3rd ed. Krieger Publ., Malabar, Fla.

Couch, H.B. and J.R. Bloom. 1960. The influence of environment on diseases of turfgrasses. II. Effect of nutrition, $\mathrm{pH}$ and soil moisture on Sclerotinia dollar spot. Phytopathology 50:761-763.

Couch, H.B. and B.D. Smith. 1991. Increase in incidence and severity of target turfgrass diseases by certain fungicides. Plant Dis. 75:1064-1067.

Danneberger, T.K., J.M. Vargas, Jr., and A.L. Jones. 1984. A model for weather-based forecasting of anthracnose on annual bluegrass. Phytopathology 74:448-451.

Detweiler, A.R., J.M. Vargas, Jr., and T.K. Danneberger. 1983. Resistance of Sclerotinia homoeocarpa to iprodione and benomyl. Plant Dis. 67:627-632.

Doney, J.C., Jr. and P. Vincelli. 1993. Cross resistance in Sclerotinia homoeocarpa to DMI fungicides. Phytopathology 83:1338 (Abstr.).
Doney, J.C., Jr., P. Vincelli, and A.J. Powell, Jr. 1994 Reactions of bentgrass to dollar spot, 1993. Biol. Cult. Tests Control Plant Dis. 9:146.

Dumont, K.P. and R.P. Korf. 1971. Sclerotiniaceae I. Generic nomenclature. Mycology 63:157.

Elliston, J.E. 1982. Hypovirulence, p. 1-33. In: D.S. Ingram and P.H. Williams (eds.). Advances in plant pathology. vol. 1. Academic, Toronto.

Endo, R.M. 1963. Influence of temperature on rate of growth of five fungal pathogens of turfgrass and on rate of disease spread. Phytopathology 53:857861.

Endo, R.M. 1966. Control of dollar spot of turfgrass by nitrogen and its probable basis. Phytopathology 56:877 (Abstr.).

Fenstermacher, J.M. 1970. Variation within Sclerotinia homoeocarpaF.T. Bennett. MSc Thesis, Univ. of Rhode Island, Kingston.

Fenstermacher, J.M. 1980. Certain features of dollar spot disease and its causal organism, Sclerotinia homoeocarpa, p. 49-53. In: B.G. Joyner and P.O. Larsen (eds.). Advances in turfgrass pathology. Harcourt Brace Jovanovich, Duluth, Minn.

Fidanza, M.A.,P.H. Dernoeden, and A.P. Grybauskas. 1996. Development and field evaluation of a brown patch warning model for perennial ryegrass turf. Phytopathology 86:385-390.

Freeman, T.E. 1967. Diseases of southern turfgrasses Florida Agr. Expt. Sta. Tech. Bul. 713.

Freeman, T.E. 1969. Influence of nitrogen sources on growth of Sclerotinia homoeocarpa. Phytopathology 59:114 (Abstr.)

Gibeault, V.A. and S.T. Cockerham. 1985. Turfgrass water conservation. California Coop. Ext. Publ. No. 21405.

Gillespie, T.J. and J. C Sutton. 1979. A predictive scheme for timing fungicide applications to control alternaria leaf blight in carrots. Can. J. Plant Pathol. 1:95-99.

Gleason, H.A. and A. Cronquist. 1991. Manual of vascular plants of northeastern United States and adjacent Canada. 2nd ed. New York Bot. Garden, New York.

Gleason, M.L., A.A. MacNab, R.E. Pitblado, M.D. Ricker, D.A. East, and R.X. Latin. 1995. Diseasewarning systems for processing tomatoes in eastern North America: Are we there yet? Plant Dis. 79:113-121.

Goldberg, C.W. and H. Cole, Jr. 1973. In vitro study of benomyl tolerance exhibited by Sclerotinia homoeocarpa. Phytopathology 58:1616-1619.

Golembiewski, R.C., J.M. Vargas, Jr., A.L. Jones and A.R. Detweiler. 1995. Detection of demethylation inhibitor (DMI) resistance in Sclerotinia homoeocarpa populations. Plant Dis. 79:491-493.

Goodman, D.M. and L.L. Burpee. 1991. Biological control of dollar spot disease of creeping bentgrass. Phytopathology 81:1438-1446.

Gordon, A.M., G.A. Surgeoner, J.C. Hall, J.B. FordRobertson, and T.J. Vyn. 1996. Letter to the editor. J. Environ. Quality 25:206-208.

Grebus, M.E., J.W. Rimelspach, and H.A.J. Hoitink. 1995. Control of dollar spot of turf with biocontrol agent-fortified compost topdressings. Phytopathology 85:1166. (Abstr.)

Gudauskas, R.T. and N.E. McGlohon. 1964. Sclerotinia blight of bahia grass in Alabama. Plant Dis. Rptr. 48:418.

Halcrow, J.G. 1965. Turf disease notes, 1965. J. Sports Turf Res. Inst. 41:53-58.

Hall, R. 1984. Relationship between weather factors and dollar spot of creeping bentgrass. Can. J. Plant Sci. 64:167-174.

Haygood, R.A. and A.R. Mazur. 1990. Evaluation of Gliocladium virens as a biocontrol agent of dollar spot on bermudagrass. Phytopathology 80:435.

Herr, L.J. 1995. Biological control of Rhizoctonia solani by binucleate Rhizoctonia spp. and hypovirulent $R$. solani agents. Crop Prot. 14:179186. 
Hitchcock, A.S. 1971. Manual for the grasses of the United States. 2nd ed. Dover, New York.

Hodges, C.F., W.M. Blaine, and P.W. Robinson. 1975. Severity of Sclerotinia homoeocarpa blight on various cultivars of fine-leaved fescues. Plant Dis. Rptr. 59:12-14.

Hodges, C.F., D.A. Campbell, and N. Christians. 1994. Potential biocontrol of Sclerotinia homoeocarpa and Bipolaris sorokiniana on the phylloplane of Poa pratensis with strains of Pseudomonas spp. Plant Pathol. 43:500-506.

Hoover, R.J. and T.A. Kucharek. 1995. First report of a leaf spot on perennial peanut caused by Sclerotinia homoeocarpa. Plant Dis. 79:1249.

Hoyland, B.F. and P.J. Landschoot. 1993. Effect of various nitrogen $(\mathrm{N})$ sources on dollar spot suppression, 1992. Biol. Cult. Tests Control Plant Dis. 8:112.

Hsiang, T. 1995. Resistance of bentgrass cultivars to dollar spot disease, 1991-1994. Biol. Cult. Tests Control Plant Dis. 10:30.

Hsiang, T., L. Yang, and W. Barton. 1997a. Baseline sensitivity and cross-resistance to demethylationinhibiting fungicides in Ontario isolates of Sclerotinia homoeocarpa. Eur. J. Plant Pathol. 103:409-416.

Hsiang, T., L. Yang, and W. Barton. 1998. Relative virulence of isolates of Sclerotinia homoeocarpa with varying sensitivity to propiconazole. Eur. J. Plant Pathol. 104:163-169.

Jackson, N. 1973. Apothecial production in Sclerotinia homoeocarpa F.T. Bennett. J. Sports Turf. Res. Inst. 49:58-63.

Kohn, L.M. 1979a. A monographic revision of the genus Sclerotinia. Mycotaxon 9:365-444.

Kohn, L.M. 1979b. Delimitation of the economically important plant pathogenic Sclerotinia species. Phytopathology 69:881-886.

Landschoot, P.J. and A.S. McNitt. 1997. Effect of nitrogen fertilizers on suppression of dollar spo disease of Agrostis stolonifera L. Intl. Turf. Soc. Res. J. 8:905-911.

Liu, L.X., T. Hsiang, K. Carey, and J.L. Eggens. 1995. Microbial populations and suppression of dollar spot disease in creeping bentgrass with inorganic and organic amendments. Plant Dis. 79:144-147.

Lo, C.T., E.B. Nelson, and G.E. Harman. 1996. Biological control of turfgrass diseases with a rhizosphere competent strain of Trichoderma harzianum. Plant Dis. 80:736-741.

Lo, C.T., E.B. Nelson, and G.E Harman. 1997. Improved biocontrol efficacy of Trichoderma harzianum 1295-22 for foliar phases of turf diseases by use of spray applications. Plant Dis. 81:1132-1138.

Madden, L. S.P. Pennypacker, and A.A. MacNab. 1978. FAST, a forecasting system for Alternaria solani in tomato. Phytopathology 68:1354-1358.

Malca, I. and R.M. Endo. 1965. Identification of galactose in cultures of Sclerotinia homoecarpa [sic] as the factor toxic to bentgrass. Phytopathology 55:775-780

Markland, F.E., E.C. Roberts, and L.R. Frederick. 1969. Influence of nitrogen fertilizers on Washington creeping bentgrass, Agrostis palustris Huds II. Incidence of dollar spot, Sclerotinia homoeocarpa, infection. Agron. J. 61:701-705.

Massie, L.B., H. Cole, and J. Duich. 1968. Pathogen variation in relation to disease severity and control of Sclerotinia dollarspot of turfgrass by fungicides. Phytopathology 58:1616-1619.

Melzer, M.J. and G.J. Boland. 1998. Evaluation of Trichoderma harzianum treatments for dollar spo suppression, 1997. Biol. Cult. Tests Control Plant Dis. 13:141.

Mills, G. and J.D. Rothwell. 1982. Predicting diseases-The hygrothermograph. Greenmaster $8: 14-15$.
Monteith, J. and A.S. Dahl. 1932. Turfgrass disease and their control. Bul. U.S. Golf Assn. 12:85

Moss, W.P., A.K. Hagan, and K.L. Bowen. 1995a Reaction of bermudagrass cultivars and selections to dollar spot in Alabama, 1994. Biol. Cult. Tests Control Plant Dis. 10:33.

Moss, W.P., A.K. Hagan, and K.L. Bowen. 1995b Reaction of zoysiagrass cultivars and selections to dollar spot in Alabama, 1994. Biol. Cult. Tests Control Plant Dis. 10:43.

Myer, J.R. and C.A. Smejkal. 1995. Response of creeping and colonial bentgrass varieties to dollar spot, 1994. Biol. Cult. Tests Control Plant Dis. 10:29.

Nelson, E.B. and C.M. Craft. 1991a. Suppression of dollar spot with top-dressings amended with composts and organic fertilizers, 1989. Biol. Cult. Tests Control Plant Dis. 6:93.

Nelson, E.B. and C.M. Craft. 1991b. Introduction and establishment of strains of Enterobacter cloacae in golf course turf for the biological control of dollar spot. Plant Dis. 75:510-514.

Nelson, E.B. and C.M. Craft. 1992. Suppression of dollar spot on creeping bentgrass and annual bluegrass turf with compost amended topdressings. Plant Dis. 76:954-958.

Nicholson, J.F., W.A. Meyer, J.B. Sinclair, and J.D. Butler. 1971. Turf isolates of Sclerotinia homoeocarpa tolerant to dyrene. Phytopathology 72:169-172.

Nutter, F.W., H. Cole, Jr., and R.D. Schein. 1983. Disease forecasting system for warm weather Pythium blight of turfgrass. Plant Dis. 67:11261128

Rodriguez, F. and W.F. Pfender. 1997. Antibiosis and antagonism of Sclerotinia homoeocarpa and Drechslera poae by Pseudomonas fluorescens Pf5 in vitro and in planta. Phytopathology 87:614 621.

Rossman, A.Y.,Palm, M.E., and L.J. Spielman. 1987. A literature guide for the identification of plant pathogenic fungi. Amer. Phytopath. Soc., St. Paul, Minn.

Sanders, D.L., W.J. Houser, P.J. Parish, and H. Cole, Jr. 1985. Reduced-rate fungicide mixture to delay fungicide resistance and to control selected turfgrass diseases. Plant Dis. 69:939-943.

Schroeder, C.B. and H.B. Sprague. 1994. Turfgrass management handbook. 4th ed. Interstate Publ. Danville, Ill.

Schumann, G.L., B.B. Clarke, L.V. Rowley, and L.L. Burpee. 1994. Use of environmental parameters and immunoassays to predict Rhizoctonia blight and schedule fungicide applications on creeping bentgrass. Crop Prot. 13:211-218

Schumann, G.L. and H.M. Reuter. 1993. Suppression of dollar spot with wheat bran top-dressings, 1992. Biol. Cult. Tests Control Plant Dis. 8:113.

Simmonds, J.H. 1958. Science branch, plant pathology section. Rev. Appl. Mycol. 38:296-297. (Abstr.)

Smiley, R.W. 1983. Compendium of turforass diseases. Amer. Phytopath. Soc., St. Paul, Minn.

Smiley, R.W. and M.M. Craven. 1979. Microflora of turfgrass treated with fungicides. Soil. Biol. Biochem. 11:349-353.

Smiley, R.W., P.H. Dernoeden, and B.B. Clarke. 1992. Compendium of turfgrass diseases. 2nd ed. Amer. Phytopath. Soc., St. Paul, Minn.

Smith, J.D. 1955. Fungi and turf diseases. J. Sports Turf Res. Inst. 9:35-59.

Smith, J.D. 1959. The effect of species and varieties of grasses on turf diseases. Rev. Appl. Mycol. 38:603-604. (Abstr.)

Smith, J.D., N. Jackson, and A.R. Woolhouse. 1989. Fungal diseases of amenity turf grasses. 3rd ed. E. \& F.N. Spon, New York.

Smith, J.P. Jr. 1977. Vascular plant families. Mad River Press, Eureka, Calif.
Soika, M.D. and P.L. Sanders. 1991. Effects of various nitrogen sources, organic amendments and biological control agents on turfgrass quality and disease development, 1990. Biol. Cult. Tests Control Plant Dis. 6:91

Sprague, R.I. 1950. Diseases of cereals and grasses in North America. Ronald Press, New York.

U.S. Dept. of Agriculture. 1960. Index of plant diseases in the United States. U.S. Dept. Agr. Hdbk. No. 165.

Urech, P.A. 1988. Companion products for use in fungicide resistance strategies. p. 95-97. In: Charles Delp (ed.). Fungicide resistance in North America. Amer. Phytopath. Soc., St. Paul, Minn.

Vargas, J.M., Jr . 1994. Management of turfgrass diseases. 2nd ed. Lewis Publ., Boca Raton, Fla.

Vargas, J.M., Jr., R. Golembiewski, and A.R. Detweiler. 1992. Dollar spot resistance to DMI fungicides. Golf Course Mgt. 60(3):50-54.

Vargas, J.M., Jr. and J.F. Powell. 1997. Mycelial compatibility and systematics of Sclerotinia homoeocarpa. Phytopathology 87:S79. (Abstr.)

Vincelli, P. and J.C. Doney. 1997. Evaluations of fungicides for control of dollar spot of creeping bentgrass, 1996. Fungicide Nematicide Tests 52:377-378

Vincelli, P., J.C. Doney, and A.J. Powell. 1996. Evaluation of fungicides for control of dollar spot, 1995. Fungicide Nematicide Tests 51:363.

Vincelli, P., J.C. Doney, Jr., and A.J. Powell. 1997. Variation among creeping bentgrass cultivars in recovery from epidemics of dollar spot. Plant Dis. 81:99-102.

Warren, C.G., P.L. Sanders, and H. Cole, Jr. 1974. Sclerotinia homoeocarpa tolerance to benzimidazole configuration fungicides. Phytopathology 64:1139-1142.

Warren, C.G., P.L. Sanders, H. Cole, Jr., and J.M. Duich. 1977. Relative fitness of benzimidazoleand cadmium-tolerant populations of Sclerotinia homoeocarpa in the absence and presence of fungicides. Phytopathology 67:704-708.

Watkins, J.E. and L.A. Wit. 1995. Effect of nitrogen rate and carrier on the suppression of dollar spot symptoms on Penncross bentgrass, 1994. Biol. Cult. Tests Control Plant Dis. 10:37.

Whetzel, H.H. 1945. A synopsis of the genera and species of the Sclerotiniaceae, a family of stromatic inoperculate discomycetes. Mycology 37:648-714.

Whetzel,H.H. 1946. The cypericolous and juncicolous species of Sclerotinia. Farlowia 2:385-437.

White, W.L. 1941. A monograph of the genus Rutstroemia (Discomycetes). Lloydia 4:153.

Wilkinson, J.F., D.P. Martin, and P.O. Larsen. 1975. Kentucky bluegrass and perennial ryegrass cultivar susceptibility to sclerotinia dollar spot. Plant Dis. Rptr. 59:935-938.

Williams, D.W. 1993. The response of dollar spot to dew removal from creeping bentgrass. MS Thesis, Univ. of Kentucky.

Williams, D.W. 1996. The role(s) of dew in the epidemiology of dollar spot. PhD Diss., Univ. of Kentucky.

Williams, D.W., A.J. Powell, P.C. Vincelli, and C.T. Dougherty. 1996. Dollar spot on bentgrass influenced by displacement of leaf surface moisture, nitrogen and clipping removal. Crop Sci. 36:13041309.

Zhou, T. and G.J. Boland. 1997. Hypovirulence and double-stranded RNA in Sclerotinia homoeocarpa. Phytopathology 87:147-153.

Zhou, T. and G.J. Boland. 1998a. Biological control strategies for Sclerotinia diseases, p. 127-156. In: G.J. Boland and L.D. Kuykendall (eds.). Plantmicrobe interactions and biological control. Marcel Dekker, New York.

Zhou, T. and G.J. Boland. 1998b. Suppression of dollar spot by hypovirulent isolates of Sclerotinia homoeocarpa. Phytopathology 88:788-794. 